\title{
NOTA/NOTE
}

\section{La recuperación ambiental de los principales destinos de interés turístico del Caribe colombiano que generó la cuarentena del Covid-19}

\section{The environmental recovery of the main tourist destinations in the Colombian Caribbean during the Covid-19 quarantine}

\author{
Marco Correa-Ramirez*, Wilberto Pacheco y Constanza Ricaurte-Villota \\ $\begin{array}{lll}\text { (iD) } 0000-0002-4714-9553 & \text { (iD } 0000-0002-1044-7848 & \text { (iD) } 0000-0003-1554-4994\end{array}$
}

\begin{abstract}
1. Programa de Geociencias, Instituto de investigaciones Marinas y Costeras "José Benito Vives de Andréis" (Invemar), Santa Marta D.T.H.C., Colombia.marco.correa.r@gmail.com*,wilberto.pacheco@invemar.org.co,constanza.ricaurte@invemar.org.co

* Autor de correspondencia
\end{abstract}

\section{RESUMEN}

$\mathrm{P}$ ara contrarrestar la propagación de la enfermedad pandémica del Covid-19, el gobierno de Colombia decretó un periodo de cuarentena de marzo 24 a julio 1 de 2020, que obligó al cese de las actividades turísticas y al cierre de los principales destinos turísticos del Caribe colombiano: Santa Marta, Cartagena y San Andrés. Durante este periodo se percibió un incremento significativo en la calidad ambiental de estas zonas costeras. Para cuantificar los cambios ambientales en la zona costera, se analizó la variación en la concentración de la clorofila y los sólidos suspendidos totales de la misión satelital Sentinel-3, 30 días antes y después del inicio de la cuarentena. Los resultados mostraron una disminución en la concentración de clorofila (> $20 \%)$ y sólidos suspendidos (> $40 \%)$ frente a Santa Marta y Cartagena, pero ningún cambio significativo en San Andrés. Aunque parte de esta reducción estuvo vinculada a cambios estacionales en forzantes locales, los resultados sugieren que la recuperación ambiental podría ser un efecto remoto del cese de actividades contaminantes en el territorio continental. Así, la cuarentena Covid-19 proporciona un referente para observar efectos de las actividades productivas y turísticas, potencialmente útil para establecer la capacidad de carga y recuperación de ecosistemas costeros.

PALABRAS CLAVE: Zona costera, indicadores ambientales, sensoramiento remoto, calidad ambiental, Covid-19

\section{ABSTRACT}

$\mathrm{T}$ o counteract the spread of the Covid-19 pandemic disease, the Colombian government decreed a quarantine period from March 24 to July 1, 2020, which forced the cessation of tourist activities and the closure of the main tourist destinations of the Colombian Caribbean: Santa Marta, Cartagena, and San Andrés. During this period, a significant increase in the environmental quality of these coastal zones was perceived. To quantify environmental changes in the coastal zone, the variation in chlorophyll concentration and total suspended solids observed by the Sentinel-3 satellite mission, 30 days before and after the start of the quarantine, was analyzed. The results showed a decrease in the concentration of chlorophyll (>20\%) and suspended solids (>40\%) in Santa Marta and Cartagena, but no significant change in San Andrés. Although part of this reduction was linked to seasonal changes in local forces, the results suggest that environmental recovery could be a remote effect of the cessation of polluting activities in the continental territory. Thus, the Covid-19 quarantine provides a reference to observe the effects of productive and tourist activities, potentially useful to establish the carrying capacity and recovery of coastal ecosystems.

KEYWORDS: Coastal zone, environmental indices, remote sensing, environmental quality, Covid-19

DOI: https://doi.org/10.25268/bimc.invemar.2021.50.2.1033 
El Covid-19 es una enfermedad altamente infecciosa causada por un nuevo tipo de coronavirus que fue notificado por primera vez en Wuhan (China) el 31 de diciembre de 2019 (OMS, 2020). Las primeras alertas de la enfermedad del Covid-19 fueron emitidas a principios de enero de 2020 pero debido a la rapidez de su propagación el 11 marzo es declarada pandemia por la Organización Mundial de la Salud (OMS). Según el Ministerio de Salud, el primer brote en Colombia se presentó el 6/3/2020. Para disminuir el contagio y evitar el colapso de los servicios de salud, el 17/3/2020 la presidencia de Colombia declaró el estado de Emergencia Económica, Social y Ecológica en todo el territorio nacional (Decreto 417) y ordenó el primer periodo de Aislamiento Preventivo Obligatorio entre el 25/3/2020 al 13/4/2020 (Decreto 457), el cual fue prolongado sucesivamente del 13-27/4/2020 (Decreto 531), del 27/4/2020-11/5/2020 (Decreto 539), del 11-25/5/2020 (Decreto 636), del 25-31/5/2020 (Decreto 639) y del 1/6/20201/7/2020 (Decreto 749). Durante este periodo de cuarentena se restringió la libre movilización de las personas y vehículos en el territorio nacional, se cancelaron los vuelos nacionales e internacionales, se cerraron las vías nacionales, se prohibió el tráfico marítimo nacional e internacional y se cerraron las playas turísticas.

La cuarentena del Covid-19 ha tenido un profundo impacto en la industria turística de Colombia. El aislamiento obligatorio y el cierre de aeropuertos y terminales terrestres y marítimos, ha bajado la ocupación hotelera hasta en $94 \%$ respecto al mismo periodo de 2019 (DANE, 2020a, 2020b). En los últimos años el turismo se había consolidado como un renglón promisorio para la economía nacional, contribuyendo a 3,83 \% del PIB de Colombia, siendo las ciudades caribeñas de Cartagena, San Andrés y Santa Marta los principales destinos turísticos de Colombia (DANE, 2018). Para 2018 Cartagena fue la segunda ciudad del país más visitada por turistas extranjeros, fue la tercera con más turistas nacionales y se consolidó como el principal receptor de cruceros turísticos (Tabla 1). Igualmente, en Santa Marta y San Andrés el arribo de turismo nacional e internacional ha incrementado en los últimos años (Mincit, 2018). Con la declaración de cuarentena la actividad turística en estas ciudades fue paralizada, mientras se desarrollan nuevas medidas que contemplan la adopción de protocolos de bioseguridad para la reapertura de un nuevo tipo turismo post Covid-2019.

La industria del turismo inició en Colombia en los años setenta de manera espontánea sin planificación, con la construcción de grandes edificaciones hoteleras en áreas muy cercanas a la línea de costa, que incrementaron el vertimiento de residuos sin tratamiento al mar, generando la mayor parte de
The Covid-19 is a highly infectious disease caused by a new type of coronavirus that was first reported in Wuhan (China) on December 31, 2019 (OMS, 2020). The first alerts of the disease were issued in early January 2020 but due to the speed of its spread, on March 11 it was declared a pandemic by the World Health Organization (WHO). According to the Ministry of Health, the first outbreak in Colombia occurred on $3 / 6 / 2020$. To reduce contagion and prevent the collapse of health services, on 3/17/2020 the Presidency of Colombia declared an Economic, Social and Ecological Emergency (Decree 417) and ordered the first period of Mandatory Preventive Isolation between $25 / 3 / 2020$ to $13 / 4 / 2020$ (Decree 457), which was extended successively from 13 to 27/4/2020 (Decree 531), from 04/27/2020 to 11/5/2020 (Decree 539), from 11-25/5/2020 (Decree 636), from 25-31/5/2020 (Decree 639) and from 1/6/2020-1/7/2020 (Decree 749). During the quarantine period, the free movement of people and vehicles was restricted, national and international flights were canceled, national roads were closed, maritime traffic was prohibited, and tourist beaches were closed.

The Covid-19 quarantine had a profound impact on Colombia's tourism industry. The mandatory isolation and closure of airports, land and maritime terminals, has reduced hotel occupancy by up to $94 \%$ compared to the same period in 2019 (DANE, 2020a, 2020b). In recent years, tourism had established itself as a promising line for the national economy, contributing $3.83 \%$ of Colombia's GDP, with the Caribbean cities of Cartagena, San Andrés and Santa Marta being the most dynamic tourist destinations (DANE, 2018). For 2018 Cartagena was the second city in the country most visited by foreign tourists, it was the third with the most national tourists and it was consolidated as the main recipient of tourist cruises (Table 1). Likewise, in Santa Marta and San Andrés the arrival of national and international tourism has increased in recent years (MINCIT, 2018). With the declaration of quarantine, the tourist activity in these cities is paralyzed, while new measures are being developed that contemplate the adoption of biosafety protocols for the reopening of a new type of post-Covid-2019 tourism.

The tourism industry began in Colombia in the 1970s spontaneously and without planning, with the construction of large hotel buildings in areas very close to the coast line, which increased the dumping of untreated waste into the sea, generating the majority of current environmental problems observed in coastal ecosystems. Since 2016, the growing influx of tourists has generated overcrowding events on the most popular beaches such as Barú (Cartagena) and El 
Tabla 1. Arribo de turistas a los principales destinos turísticos del Caribe colombiano entre 2017-2019 (Citur, 2019).

Table 1. Tourists arrival to the main tourist destinations in the Colombian Caribbean between 2017-2019 (Citur,2019).

\begin{tabular}{|c|c|c|c|c|}
\hline Destino / Destination & Transporte / Transportation & 2017 & 2018 & 2019 \\
\hline \multirow{3}{*}{ Cartagena } & Vuelos nacionales / Domestic flights & $1,901,786$ & $2,133,115$ & $1,085,803$ \\
\hline & Vuelos internacionales / International flights & 361,824 & 485,464 & 262,071 \\
\hline & Cruceros / Cruises & 331,335 & 360,489 & 193,182 \\
\hline \multirow{3}{*}{ Santa Marta } & Vuelos nacionales / Domestic flights & 820,046 & 977,562 & 566,775 \\
\hline & Vuelos internacionales / International flights & 0 & 1,855 & 8,090 \\
\hline & Cruceros / Cruises & 13,289 & 17,592 & 12,637 \\
\hline \multirow{3}{*}{ San Andrés } & Vuelos nacionales / Domestic flights & 943,570 & 944,013 & 510,172 \\
\hline & Vuelos internacionales / International flights & 52,616 & 45,594 & 23,965 \\
\hline & Cruceros / Cruises & 0 & 0 & 551 \\
\hline
\end{tabular}

los problemas actuales de degradación ambiental observados en los ecosistemas costeros del país (Williams et al., 2016). Desde 2016 la creciente afluencia de turistas ha generado eventos de sobreocupación de las playas de mayor demanda como Barú (Cartagena) y El Rodadero (Santa Marta), en las cuales más de 7000 turistas por día acuden sin control a las playas durante las temporadas vacacionales, acelerando los procesos erosivos, la contaminación y la degradación de los ecosistemas costeros (El Tiempo, 2017; Rangel et al., 2018).

La interrupción súbita de la presión turística determinada por la cuarentena del Covid-19 ha hecho notoria una rápida recuperación ambiental de las zonas costeras durante las primeras semanas de la cuarentena. La publicación de fotos y videos en varios medios de comunicación, donde se observa el regreso de delfines, tortugas y aves playeras, junto con el renovado color azul de las aguas demuestran el efecto benéfico de la cuarentena en la calidad ambiental de las zonas costeras (Botero et al., 2020). Sin embargo, más allá de estas primeras observaciones se desconoce aún la magnitud y los factores que propician esta recuperación ambiental.

Ante la escasez de plataformas observacionales e información actualizada de los principales destinos turísticos del Caribe colombiano (Cartagena, Santa Marta y San Andrés), para describir los cambios ambientales durante la cuarentena se analizaron datos satelitales de Clorofila-a (Chl-a) y de Sólidos Suspendidos Totales (SST) durante 30 días antes (21/2/2020$23 / 3 / 2020)$ y 30 días después (24/3/2020-21/4/2020) del inicio de la cuarentena (24/3/2020), registrados por el Instrumento de Color de Océano y la Tierra (OLCI) nivel-2 (L2) abordo de la misión satelital SENTINEL-3 a una resolución de $300 \mathrm{~m}$ (https://coda.eumetsat.int/\#/home). Tanto la Chl-a y los SST son parámetros frecuentemente utilizados para monitorear la calidad del agua en zonas costeras y lagos. La Chl-a es una medida de abundancia de fitoplancton y un indicador de eutrofización,
Rodadero (Santa Marta), in which more than 7,000 tourists per day fill uncontrollably the beaches during the holiday seasons, accelerating erosive processes, pollution and degradation of coastal ecosystems (Williams et al., 2016; El Tiempo, 2017; Rangel et al., 2018).

The sudden interruption of the tourist pressure determined by the Covid-19 quarantine has favored a rapid environmental recovery of the coastal areas during the first weeks of the quarantine. The publication of photos and videos in various media, where the return of dolphins, turtles and shorebirds is observed, together with the renewed blue color of the waters, shows the beneficial effect of quarantine on the environmental quality of coastal zone (Botero et al., 2020). However, beyond these first observations, the magnitude and factors that promote this environmental recovery are still unknown.

Given the scarcity of observational platforms and updated information on the main tourist destinations of the Colombian Caribbean (Cartagena, Santa Marta and San Andrés), to describe environmental changes during the quarantine, satellite data of Chlorophyll-a (Chl-a) and Total Suspended Solids (TSS) were analyzed for 30 days before (21/2/2020 to $23 / 3 / 2020)$ and 30 days after (24/3/2020 to $21 / 4 / 2020)$ of the start of the quarantine $(24 / 3 / 2020)$, recorded by the Ocean Land Color Instrument (OLCI) level-2 aboard the Sentinel-3 mission at a resolution of $300 \mathrm{~m}$ (https://coda. eumetsat.int/\#/home). Both Chl-a and TSS are parameters frequently used to monitor water quality in coastal areas and lakes. The Chl-a is a measure of phytoplankton abundance and a proxy of eutroficarion frequently used to observe blooms due to fertilization by pollutants and nutrients, therefore it is an indicator of the health of aquatic ecosystems (Blondeau-Patissiera et al., 2014). The TSS show the concentration of non-biological particles contributed by 
frecuentemente usado para observar florecimientos debido a la fertilización por contaminantes y nutrientes, por lo que es un indicador de la salud de los ecosistemas acuáticos (BlondeauPatissiera et al., 2014). Los SST muestran la concentración de partículas no-biológicas aportadas por ríos o provenientes de la resuspensión de sedimentos (Gohin, 2011) que reducen la radiación fotosintética disponible para los ecosistemas bentónicos y pelágicos (Cole y Cloern, 1987; Tian et al., 2014). Los datos faltantes causados por la interferencia nubosa fueron restituidos mediante interpolación utilizando DINEOF (Data INterpolating Empirical Orthogonal Functions, Beckers y Rixen, 2003; Alvera-Azcárate et al., 2005). La variabilidad temporal de la Chl-a y los SST en la zona costera fue analizada mediante el promedio espacial de estas variables en los tres primeros kilómetros desde la línea de costa. Estos promedios fueron comparados con los promedios climatológicos de 10 años (2010-2019) de Chl-a y SST derivados de los datos MODIS-A, obtenidos del OceanColor Web (https://oceancolor. gsfc.nasa.gov/). Los SST de MODIS-A fueron estimados utilizando las reflectancias percibidas por satélite alrededor de $667 \mathrm{~nm}$ de longitud de onda, mediante la aproximación de Nechad et al. (2010).

En los primeros tres kilómetros de la zona costera de Santa Marta (frente a las playas de El Rodadero y Bello Horizonte), se observó una disminución de la Chl-a (de 4,38 a 3,29 $\mathrm{mg} \mathrm{m}^{-3}$ ) y los SST (de 5,60 a 3,11 $\mathrm{g} \mathrm{m}^{-3}$ ) durante el periodo de cuarentena, lo que constituye una reducción de 24,9 y $44,5 \%$ respectivamente (Fig. 1c y d). Los campos promedio de la Chl-a y los SST (Figura 1a-b y 1d-e) mostraron que esta reducción en la concentración fue mayor en la región sur más afectada por las descargas fluviales de la Ciénaga Grande de Santa Marta y el río Córdoba. Una reducción similar en la Chl-a se observó durante el mismo periodo del año anterior (2019, línea gris en Fig. 1), pero los SST de ese año se mantuvieron invariables. El promedio climatológico de la Chl-a muestran que una reducción en la concentración de Chl-a es una condición típica para esta época del año, que posiblemente se encuentre vinculada a la relajación estacional de los vientos y la surgencia costera (Correa-Ramírez et al., 2020).

Similar a lo observado en Santa Marta, frente a Cartagena se observó una reducción de $28,7 \%$ de la Chl-a (de 5,51 a 3,93 $\mathrm{mg} \mathrm{m}^{-3}$ ) y de $52,2 \%$ de los SST (de 14,70 a $7,02 \mathrm{~g} \mathrm{~m}^{-3}$ ) que no tuvo precedentes para el mismo periodo en 2019 (línea gris, Fig. 2 c y f). Los promedios climatológicos de la concentración de la Chl-a y SST (línea azul en Fig. 2) para esta región se mantienen típicamente constantes alrededor de $5 \mathrm{mg} \mathrm{m}^{-3}$ y $10 \mathrm{~g} \mathrm{~m}^{-3}$ respectivamente, por lo que la reducción observada en 2020 no es una condición esperada para esta rivers or from sediment re-suspension (Gohin, 2011) that reduce the photosynthetic radiation available for benthic and pelagic ecosystems (Cole and Cloern, 1987; Tian et al., 2014 ). The missing data caused by cloud interference were restored by interpolation using DINEOF (Data INterpolates Empirical Orthogonal Functions; Alvera-Azcárate et al., 2005; Beckers and Rixen, 2003). The temporal variability of Chl- $a$ and TSS in the coastal zone was analyzed using the spatial average of these variables in the first $3 \mathrm{~km}$ from the coastline. These averages were compared with the 10-year climatological averages (2010-2019) for Chl-a and TSS derived from MODIS-A data, obtained from OceanColor Web (https://oceancolor.gsfc.nasa.gov/).he MODIS-A TSS was estimated using the reflectances perceived by satellite around $667 \mathrm{~nm}$ wavelength, using the approximation of Nechad et al. (2010).

In the first $3 \mathrm{~km}$ of the coastal zone of Santa Marta (in front of the El Rodadero and Bello Horizonte beaches), a decrease was observed in Chl- $a$ (from 4.38 to $3.29 \mathrm{mg} \mathrm{m}^{-3}$ ) and TSS (from 5.60 to $3.11 \mathrm{~g} \mathrm{~m}^{-3}$ ) during the quarantine period, which constitutes a reduction of 24.9 and $44.5 \%$ respectively (Fig. $1 \mathrm{c}$ and d). The average fields of Chl- $a$ and TSS (Figure 1a-b and 1d-e) showed that this reduction was major in the southern region most affected by the fluvial discharge from the Ciénaga Grande de Santa Marta and the Córdova river. A similar reduction in Chl- $a$ was observed during the same period of the previous year (2019, gray line in Fig. 1), but the TSS of that year remained unchanged. The climatological average of the Chl-a shows that a reduction of Chl-a concentration is a typical condition expected for this time of year, which is possibly linked to the seasonal relaxation of the winds and the coastal upwelling (CorreaRamirez et al., 2020).

Similar to what was observed in Santa Marta, in Cartagena a reduction of $28.7 \%$ in Chl- $a$ (from 5.51 to $3.3 \mathrm{mg} \mathrm{m}^{-3}$ ) and of $52.2 \%$ in TSS (from 14.70 to $7.02 \mathrm{~g} \mathrm{~m}^{-3}$ ) was observed without precedents for the same period in 2019 (gray line, Fig. 2 c y f). The climatological averages of Chl- $a$ and TSS (blue line in Fig. 2) for this region are typically kept constant around $5 \mathrm{mg} \mathrm{m}^{-3}$ and $10 \mathrm{~g} \mathrm{~m}^{-3}$ respectively, therefore the reduction observed in 2020 is not an expected condition for this time of year. The greatest reductions occurred in the northern sector (Tierra Bomba, Boca Grande, Crespo, La Boquilla and Punta Canoas), the most affected by fluvial discharges from the Magdalena River and the Canal del Dique. In front of Barú, no significant changes in concentration were observed. 
época del año. Las mayores reducciones en las concentraciones ocurrieron en el sector norte (Tierra Bomba, Boca Grande, Crespo, La Boquilla y Punta Canoas) que se encuentra más afectado por las descargas fluviales del río Magdalena y el Canal del Dique. Frente a Barú no se observaron cambios significativos en la concentración.

A diferencia de lo observado en Santa Marta y Cartagena, en la zona costera de San Andrés las concentraciones de Chl-a y SST permanecieron invariablemente bajas antes y durante la cuarentena (líneas rojas, Fig. 3 c y f). Además, las concentraciones promedio observadas en 2020 fueron similares al promedio climatológico. Las mayores concentraciones observadas en el sector oriental de la isla (Fig. 3a-b y d-e) son posiblemente un artificio de la estimación satelital, debido a que, en este sector de baja profundidad y alta transparencia de las aguas, la reflectancia del fondo marino produce una
Unlike what was observed in Santa Marta and Cartagena, in the coastal zone of San Andrés, Chl- $a$ and TSS concentrations remained invariably low before and during the quarantine (red lines, Fig. $3 \mathrm{c}$ and f). Furthermore, the average concentrations observed in 2020 were similar to the climatological average. The highest concentrations observed in the eastern sector of the island (Fig. 3a-b and d-e) are possibly an artifact of the satellite estimation, due to the fact that in this sector of shallow depth and high water transparency, the reflectance of the seabed produce an overestimation in concentrations derived from satellite records (Cannizzaro and Carder, 2006).

The reduction observed in the concentration of Chl- $a$ and SST corroborates the recovery of the environmental quality observed during the Covid-19 quarantine in the coastal zone of the main tourist destinations in the

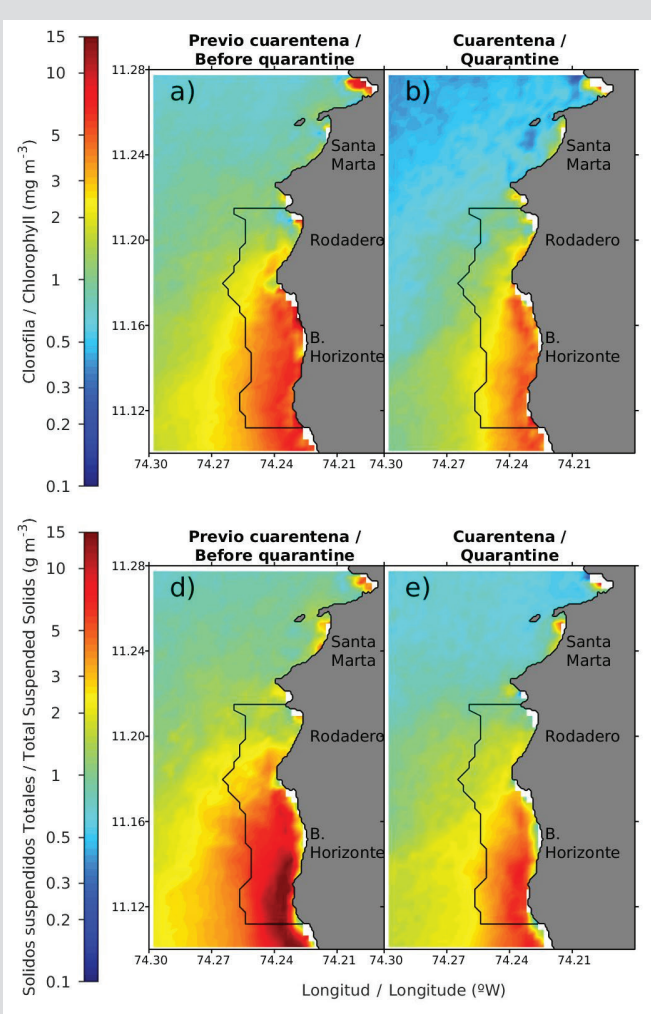

Figura 1. Concentración promedio de la Clorofila-a (a,b) - los Sólidos Suspendidos Totales $(\mathrm{d}, \mathrm{e})$ - Sentinel OLCI en la zona costera de Santa Marta, 30 días antes (a,d) y después (b,e) del inicio de la cuarentena Covid-19 (24/3/2020). En los paneles c) y f): las líneas negras muestran la evolución temporal del promedio en los primeros $3 \mathrm{~km}$ de la costa (polígono en los paneles a-b y d-e) de la Chl-a y los SST respectivamente; la línea punteada vertical muestra el inicio de la cuarentena; las líneas rojas horizontales muestran el promedio de cada variable 30 días antes del inicio y durante los primeros 30 días de la cuarentena; las líneas grises muestran las concentraciones para el mismo periodo del año anterior (2019); las líneas azules muestra el promedio climatológico calculado sobre 10 años (2010-2019) de datos Modis-Aqua y la sombra azul la desviación estándar alrededor del promedio climatológico.

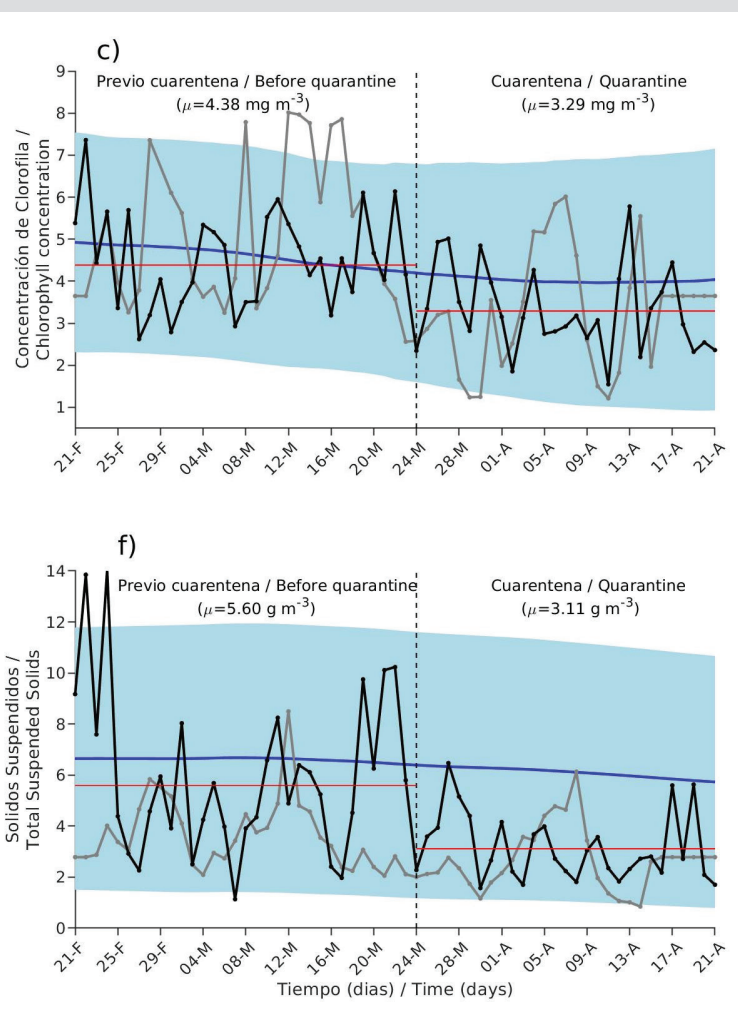

Figure 1. Average concentration of Chlorophyll-a (a, b) - Total Suspended Solids (d, e) - Sentinel OLCI in the coastal zone Santa Marta, 30 days before (a, d) and after (b, e ) of the beginning of Covid-19 quarantine (3/24/2020). In panels c) and f): the black lines show the average temporal evolution in the first $3 \mathrm{~km}$ from the coast (polygon in panels $a-b$ and d-e) of the Chl-a and SST respectively; the vertical dotted line shows the start of the quarantine; the horizontal red lines show the temporal mean of these variables 30 days before the start and during the first 30 days of the quarantine; the gray lines show the concentrations for the same period in the previous year (2019); the blue lines show the climatological average calculated over 10 years (2010-2019) from the Modis-Aqua data and the blue shaded area shows one standard deviation around the climatological average. 

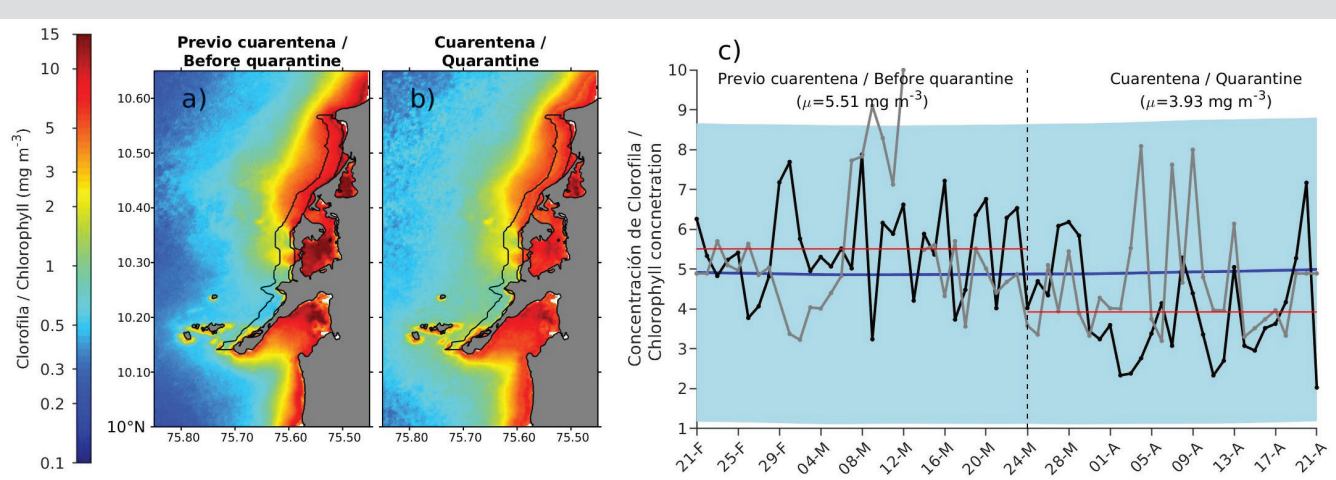

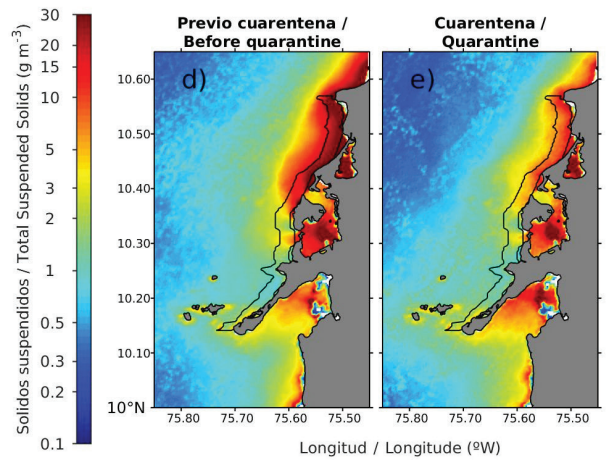

Figura 2. Concentración promedio de la Chl-a y los SST Sentinel OLCI en la zona costera de Cartagena, 30 días antes y después del inicio de la cuarentena Covid-19. La distribución de los paneles y convenciones es similar a los de la figura 1.

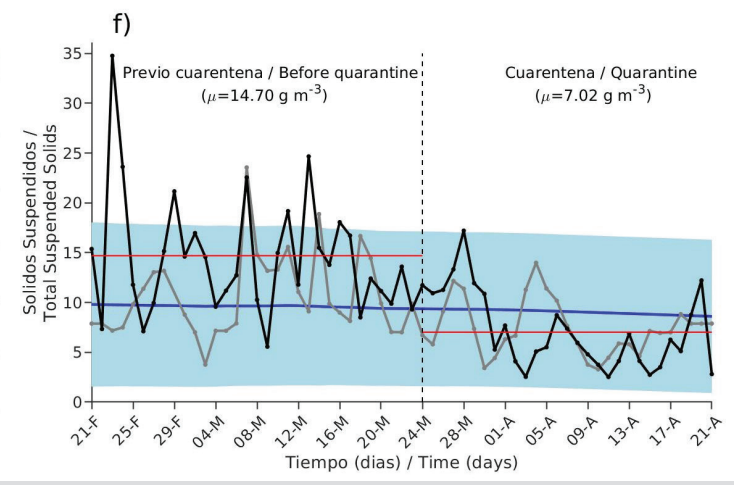

Figure 2. Average concentration of the Chl-a and the TSS Sentinel OLCI in the coastal zone off Cartagena, 30 days before and after the start of the Covid-19 quarantine. The distribution of the panels and conventions is similar to those of figure 1 . sobrestimación en las concentraciones derivadas de los registros satelitales (Cannizzaro y Carder, 2006).

La reducción observada en la concentración de Chl-a y SST corrobora la recuperación de la calidad ambiental observada durante la cuarentena Covid-19 en la zona costera de los principales destinos turísticos del Caribe continental colombiano (pertenecientes a Santa Marta y Cartagena). Aunque parte de esta reducción está vinculada a cambios estacionales en los forzantes locales (relajación de los vientos alisios y la surgencia costera), los resultados también sugieren que la recuperación ambiental observada puede no estar exclusivamente vinculada a la disminución local de la presión turística. La zona costera de Santa Marta y Cartagena es regularmente afectada por la descarga fluvial de ríos de gran caudal (como el Magdalena), que aportan una carga significativa de contaminantes, nutrientes y sedimentos (Restrepo et al., 2018; Torregroza et al., 2020). La disminución observada en la Chl-a y los SST en la zona costera puede también ser un efecto de origen remoto provocado por una mejora de la calidad de las aguas descargadas por los ríos, vinculado al cese de las actividades productivas contaminantes en el territorio continental colombiano durante el periodo de cuarentena. Esto explicaría por qué las zonas costeras insulares, las cuáles no
Colombian continental Caribbean (belonging to Santa Marta and Cartagena). Although part of this reduction is linked to seasonal changes in the local forcing (relaxation of the trade winds and coastal upwelling), the results also suggest that the observed environmental recovery cannot be exclusively linked to the local decrease in tourist pressure. The coastal zone of Santa Marta and Cartagena is regularly affected by the river discharge of large-flow rivers (like is the Magdalena river), which provide a significant load of pollutants, nutrients and sediments (Restrepo et al., 2018, Torregroza et al., 2020). The observed decrease in the Chl- $a$ and the TSS may also be an effect of remote origin caused by an improvement in the quality of the waters discharged by the rivers, linked to the cessation of polluting productive activities in the Colombian continental territory during the quarantine. This would explain why the insular coastal areas that are not directly affected by river discharges, such as San Andrés, do not present significant changes in their environmental quality. Although the cessation of tourist activity could have favored a beneficial local effect on the populations of seabirds, reptiles and marine mammals, the results suggest that the environmental quality of coastal areas is also intrinsically linked to the productive activities developed inside the national territory. 

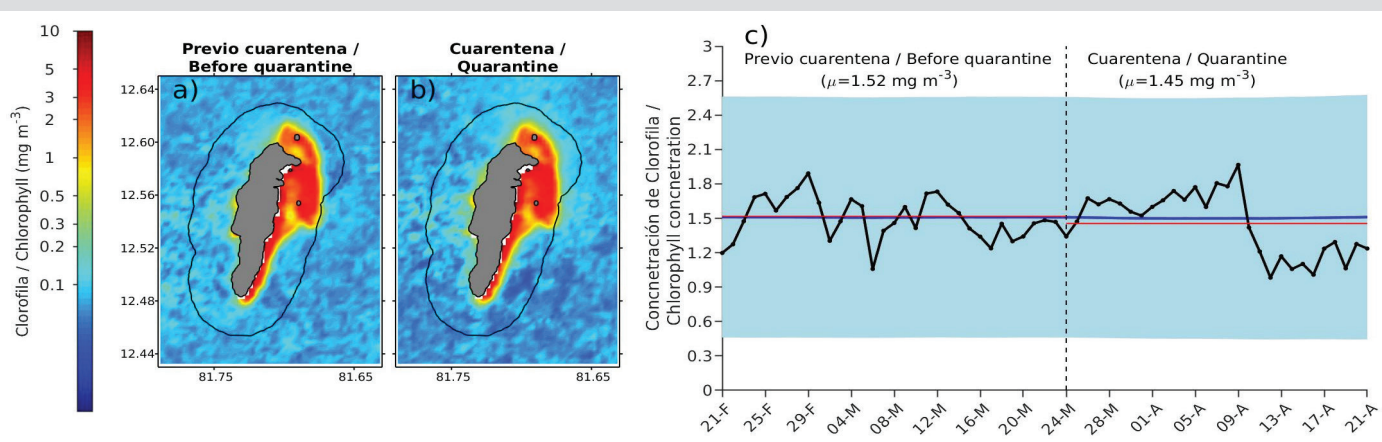
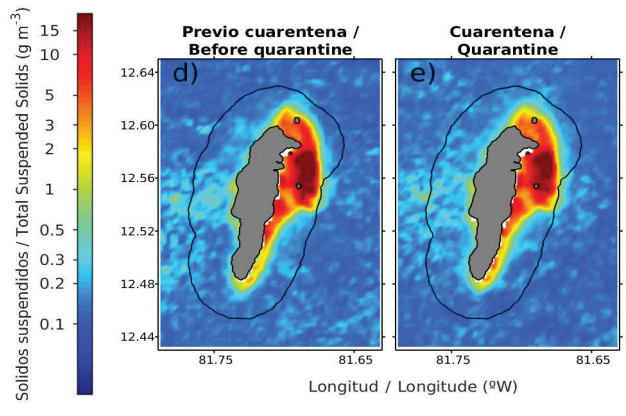

Figura 3. Concentración promedio de la Chl-a y los SST Sentinel OLCI en la zona costera de la isla de San Andrés, 30 días antes y después del inicio de la cuarentena Covid-19. La distribución de los paneles y convenciones es igual a los de la figura 1.

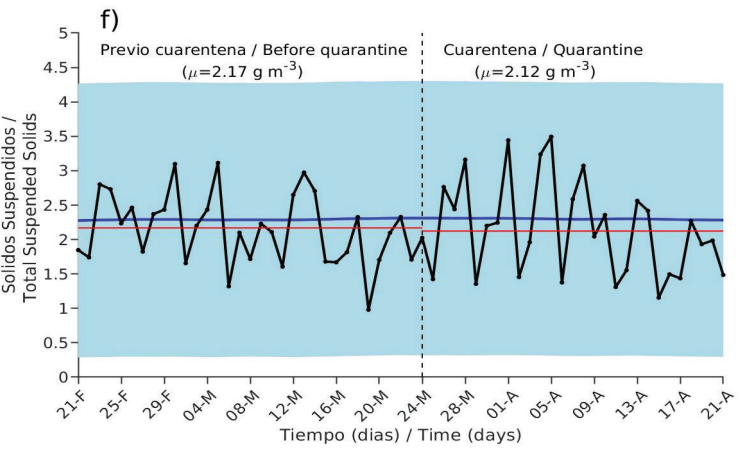

Figure 3. Average concentration of the Chl-a and the TSS Sentinel OLCI in the coastal zone off San Andres island, 30 days before and after the start of the Covid-19 quarantine. The distribution of the panels and conventions is similar to those of figure 1 . están directamente afectadas por descargas de ríos, como la de San Andrés, no presentan cambios significativos en su calidad ambiental. Aunque el cese de la actividad turística pudo haber favorecido un efecto local benéfico sobre las poblaciones de aves, reptiles y mamíferos marinos, los resultados sugieren que la calidad ambiental de las zonas costeras también está intrínsecamente vinculada a las actividades productivas desarrolladas en el interior del territorio nacional.

La cuarentena Covid-19 ha proporcionado un marco experimental sin precedentes para observar el efecto que genera la reducción de las actividades productivas y el turismo en las zonas costeras de Colombia. Más allá de las primeras observaciones proporcionadas en esta nota, el periodo de cuarentena podría constituirse como un referente para futuros estudios orientados a determinar la capacidad de carga, de recuperación y resiliencia de los ecosistemas costeros ante las actividades humanas.

\section{AGRADECIMIENTOS}

Esta investigación fue financiada por el Banco de Proyectos de Inversión Nacional (BPIN), proyecto "Investigación científica hacia la generación de información y conocimiento de las zonas marinas y costeras de interés de la nación" de Invemar.
The Covid-19 quarantine has provided an unprecedented experimental framework for observing the effect of reduced productive activities and tourism in the Colombian coastal zones. Beyond the first observations provided in this note, the quarantine period could be a benchmark for further studies to determine the carrying capacity, recovery, and resilience of coastal ecosystems to human activities.

\section{ACKNOWLEDGMENTS}

This research was funded by the Bank of National Investment Projects (BPIN), project "Scientific research towards the generation of information and knowledge on marine and coastal areas of national interest" developed by INVEMAR. 


\section{BIBLIOGRAFÍA / LITERATURE CITED}

Alvera-Azcárate, A., A. Barth, M. Rixen and J.M. Beckers. 2005. Reconstruction of incomplete oceanographic data sets using Empirical Orthogonal Functions. Application to the Adriatic Sea. Oc. Model., 9: 325-346.

Beckers, J.M. and M. Rixen. 2003. EOF calculations and data filling from incomplete oceanographic data sets. J. Atmos. Ocean. Technol., 20(12): 1839-1856.

Blondeau-Patissiera, D., J. F. R. Gowerb, A. G. Dekkercd, S. R. Phinnd and V. E. Brandocd. 2014. A review of ocean color remote sensing methods and statistical techniques for the detection, mapping and analysis of phytoplankton blooms in coastal and open oceans. Progr. Oceanogr., 123: 123-144. https://doi. org/10.1016/j.pocean.2013.12.008

Botero, C.M., S. Mercadé, J.A.Cabrera y B. Bombana (Eds.). 2020. El turismo de sol y playa en el contexto de la Covid-19; escenarios y recomendaciones. Red Iberoam. Gestión Cert. Playas -PROPLAYAS. 2020. Santa Marta. 120 p.

Cannizzaro, J. P. and K.L. Carder. 2006. Estimating chlorophyll a concentrations from remote-sensing reflectance in optically shallow waters. Rem. Sens. Environ., 101: 13-24

Cole, B.E. and J.E. Cloern. 1987. An empirical model for estimating phytoplankton productivity in estuaries. Mar. Ecol. Progr. Ser., 36(1): $299-305$.

Correa-Ramírez, M., Á. Rodríguez-Santana, C. Ricaurte-Villota and J. Paramo. 2020. The southern Caribbean upwelling system off Colombia: water masses and mixing processes. Deep Sea Res. Part I: Oceanogr. Res. Pap., 155: 103145. https://doi.org/10.1016/j.dsr.2019.103145

DANE. 2020a. Boletín técnico; muestra mensual de hoteles mes de marzo Depart. Administr. Nal. Estad. https:/www.dane.gov.co/files/investigaciones/boletines/ mmh/bol_mmh_mar20.pdf 27/07/2020.

DANE. 2020b. Boletín técnico; muestra mensual de hoteles mes de abril. Depart. Administr. Nal. Estad. https://www.dane.gov.co/files/investigaciones/boletines/ mmh/bol_mmh_abr20.pdf 27/07/2020.

Decreto 417. Por el cual se declara un Estado de Emergencia Económica, Social y Ecológica en todo el territorio Nacional, Colombia, 17 de marzo de 2020.

Decreto 457. Por el cual se imparten instrucciones en virtud de la emergencia sanitaria generada por la pandemia del Coronavirus Covid-19 y el mantenimiento del orden público, Colombia, 22 de marzo de 2020.

Decreto 531. Por el cual se imparten instrucciones en virtud de la emergencia sanitaria generada por la pandemia del Coronavirus Covid-19, y el mantenimiento del orden público, Colombia, 8 de abril de 2020.

Decreto 539. Por el cual se adoptan medidas de bioseguridad para mitigar, evitar la propagación y realizar el adecuado manejo de la pandemia del Coronavirus Covid-19, en el marco del Estado de Emergencia Económica, Social y Ecológica, Colombia, 13 de abril de 2020.

Decreto 636. Por el cual se imparten instrucciones en virtud de la emergencia sanitaria generada por la pandemia del Coronavirus Covid-19, y el mantenimiento del orden público, Colombia, 6 de mayo de 2020.

Decreto 639. Por el cual se crea el Programa de apoyo al empleo formal -PAEF, en el marco del Estado de Emergencia Económica, Social y Ecológica declarado por el Decreto 637 de 2020, Colombia, 8 de mayo de 2020.

Decreto 749. Por el cual se imparten instrucciones en virtud de la emergencia sanitaria generada por la pandemia del Coronavirus Covid-19, y el mantenimiento del orden público, Colombia, 28 de mayo de 2020.

Gohin, F. 2011. Annual cycles of chlorophyll-a, non-algal suspended particulate matter, and turbidity observed from space and in-situ in coastal waters. Oc. Sci., 7(5): 705-732. https://doi.org/10.5194/os-7-705-2011

Mincit. 2018. Resultados para el turismo. Min. Com. Industr. Turis. https://www.mincit.gov.co/getattachment/estudios-economicos/estadisticas-e-informes/ informes-de-turismo/2018/oee-vt-turismo-2018-28-03-2019.pdf.aspx

Nechad, B., K. G. Ruddick and G. Neukermans. 2010. Calibration and validation of a generic multisensor algorithm for mapping of turbidity in coastal waters. Rem. Sens. Environ., 114 (4): 854-866. https://doi.org/10.1016/j.rse.2009.11.022.

Noguera, N. 2017. Exceso de turistas y hotelería ilegal ponen en jaque a la naturaleza. El Tiempo digital. https://www.eltiempo.com/vida/medio-ambiente/turismoexcesivo-afecta-ecosistemas-en-colombia-159910 27/07/2020.

Organización Mundial de la Salud. 2019. Covid-19: cronología de la actuación de la OMS. https://www.who.int/es/news-room/detail/27-04-2020-who-timeline--covid-19 27/07/2020.

Rangel-Buitrago, N., A. Williams y G. Anfuso. 2018. Killing the goose with the golden eggs: litter effects on scenic quality of the Caribbean coast of Colombia. Mar. Poll. Bull., 127: 22-38.

Restrepo, J. D. and H.A. Escobar. 2018. Sediment load trends in the Magdalena River basin (1980-2010): Anthropogenic and climate-induced causes. Geomorphology, 302: 76-91.

Tian, L., O. W. Wai, X. Chen, Y. Liu, L. Feng, J. Li and J. Huang. 2014. Assessment of total suspended sediment distribution under varying tidal conditions in deep bay: Initial results from HJ-1A/1B satellite CCD images. Rem. Sens., 6(10): 9911-9929.

Torregroza-Espinosa, A. C., J.C. Restrepo, A. Correa-Metrio, N. Hoyos, J. Escobar, J. Pierini and J.M. Martínez. 2020. Fluvial and oceanographic influences on suspended sediment dispersal in the Magdalena River Estuary. J. Mar. Syst., 204: 103282.

Williams, A. T., N.G. Rangel-Buitrago, G. Anfuso, O. Cervantes and C. M. Botero. 2016. Litter impacts on scenery and tourism on the Colombian north Caribbean coast. Tour. Manag., 55: 209-224. 